\title{
Lånere og gæster i Det kongelige Biblioteks katalogværelse i årene ca. $1955-80$
}

[fortsat fra forrige nr.]

af fhv. forskningsbibliotekar, mag.art. Knud Bøgh

4.

Da det nye bibliotekshus åbnede i 1906, har det været imponerende ikke blot ved sit udstyr, men også ved de fornyelser og forbedringer, som mødte publikum. Blandt disse var katalogværelset, det centrale informationssted, det som med H.O. Langes ord skulle være indgangsport til biblioteket og litteraturen. Kataloger, bibliografier, håndbøger og en fast bibliotekar var her til disposition for de besøgende og rede til at besvare deres spørgsmål.

Der kom ikke så få udlændinge, og derfor havde denne bibliotekar i sin skuffe en håndskreven parlør liggende, som også i årene efter 1950 gjordenytte, men som nu må være overgået til arkivet. Den indeholdt mange biblioteksformuleringer oversat til fransk, tysk og engelsk, vistnok mest til det sidste sprog, som i begyndelsen af århundredet ikke var så kendt som $\mathrm{i}$ dag. Kneb det med at finde de rette tekniske ord for, hvordan tingene var indrettet, slog man op og fandt f.eks.: The subject catalogue is contained in the large folios next to the floor; eller: The class mark is found inside the cover. Man forestiller sig, at den tids besøgende har været påklædt som en gentleman, når parløren har en opfordring til at tage handskerne af, når han blader i den alfabetiske katalog, så man ikke beskadiger sedlerne. Endnu efter anden verdenskrig kunne man i katalogværelse opleve victoriansk levemåde. Det gav straks god kontakt og orientering at få et visitkort overrakt. En hvidhåret litograf udbad sig efter en samtale bibliotekarens "ærede navn". En herre bukkede let og spurgte, om han talte med den "jourhavende bibliotekar", der så følte sig, som sad han i et kongeligt forgemak. 
De nyeårgange siger Hej! - Der er en fyr, som hedder Rousseau. Har I noget af ham? - Det viste sig heldigvis at være tilfældet, og sågar havde vi også bøger om ham. Katalogværelset var blevet det, H.O. Lange havde ønsket: en indgang til litteraturen. Her var stedet, hvor alt det ubestemmelige, alle de løse ender havnede. For her var muligheden for at komme i kontakt med bibliotekets øvrige afdelinger, specialsamlinger, fjernere kontorer, sjældent brugte kartoteker eller opslagsværker.

Bibliotekaren lyttede til spørgsmålene og fandt frem til den afdeling eller person, som havde den bedste forudsætning for at give et sagligt svar. Bl.a. skulle der være 35 fagreferenter at vælge mellem. Meget begyndte på dette sted og endte et andet sted i huset, hvor den kompetente sad. Den vagthavende fungerede som forpost. Tit havde man gerne hørt enden på historien. Meget blev naturligt overtaget af Håndskriftsafdelingen, og det huskes med tak, at Tue Gad ofte tilfredsstillede ens nysgerrighed ved bagefter at berette om, hvad undersøgelsen var endt med. I dag kaldes det vist tilbagemelding. Kundepsykologi var det nye ord for, hvordan man bedst hjalp fremmede til rette, hvordan man kom ind til, hvad der var brug for, uden at lægge skjul på eventuel uvidenhed. Nogle forklarede beredvilligt, andre løftede brynet, når det viste sig, at bibliotekaren nu for første gang hørte om Hermes Trismegistos, de hermetiske bøger eller Horapollon. Til tider misundte man de kolleger, der sad inde bag et skrivebord og ikke havde behov for at improvisere, men kun pligt til at svare på det, de havde forstand på.

I den artikel Palle Birkelund skrev i 50. årgang (1963) af Nordisktidskrift för bok- och biblioteksväsen gives en fyldig beskrivelse af, hvordan publikumsbetjeningen dengang blev udbygget. Det fremgår også, at mange udenlandske forespørgsler gik direkte pr. brev til Rigsbibliotekarembedet, som drev en „ret udstrakt dokumentationsvirksomhed. En forespørgsel om danske deltagere $\mathrm{i}$ den græske frihedskrig resulterede således i et memorandum på ca. 20 sider, og forespørgsler om, hvordan den amerikanske borgerkrig afspejlede sig i den samtidige danske presse, eller om Atlantis i dansk litteratur krævede naturligvis også langvarige undersøgelser - for blot at nævne et par eksempler fra den ende af skalaen."

På den bredere front, i katalogværelset, i den anden ende af skalaen, landede mange af de indenlandske spørgsmål. De faglige og dybtgående var det ingen sag at sende videre - dem havde man fagreferenterne til. Men de ubestemmelige, den grå mellemvare, faldt let $i$ et tomrum mellem skrivebordene. Den føromtalte kuvert med eksempler viser, at de var brydsomme nok, for under hvilken fagreferent sorterede ballonfart, strandinger, vejrhaner, priser på gamle dukker, Rafaels ø (det var ikke maleren), 

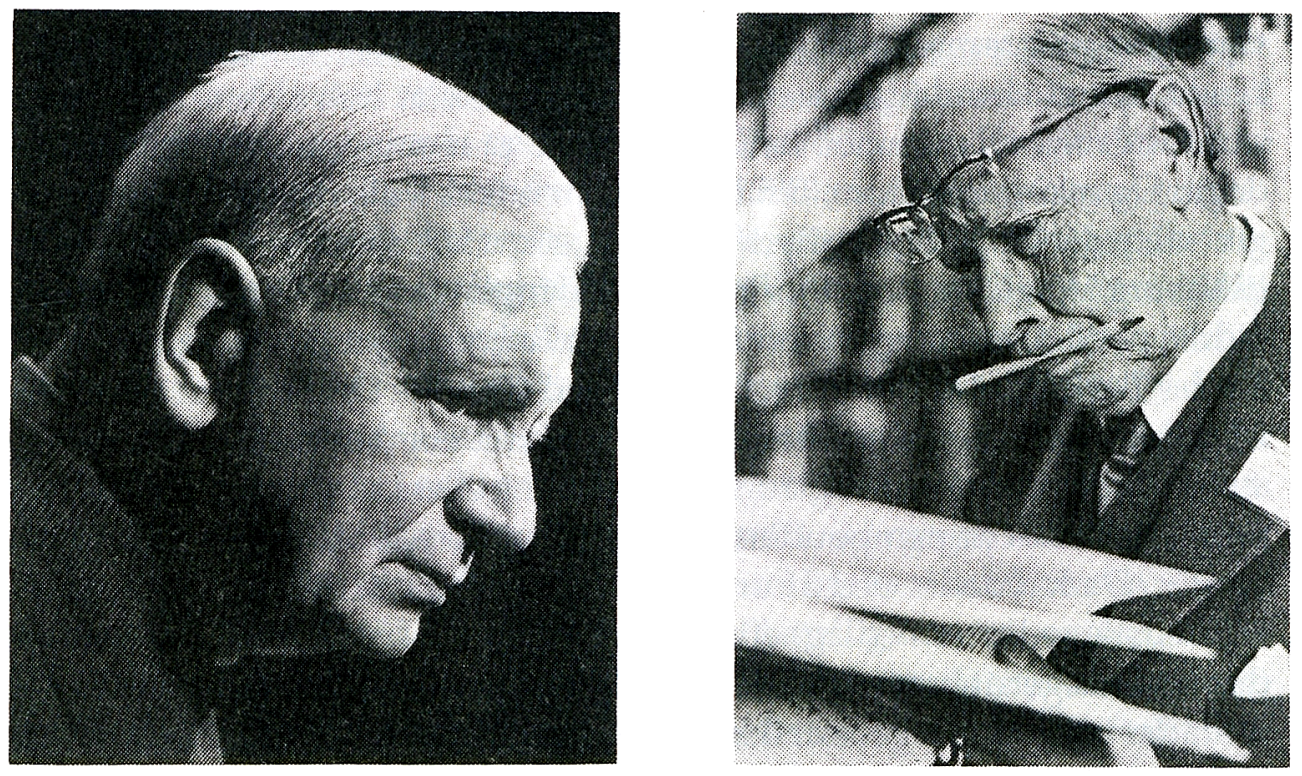

Tilvenstre filminstruktøren Carl Th. Dreyer (1889-1968). Tilhøjre litteraturhistorikeren Morten Borup (1894-1989), begge faste benyttere af Det kongelige Bibliotek og gæster i katalogværelset.

profeten Martinus (som dengang levede i bedste velgående), Tivolis kanonkonge fra 1876 ? Så kunne man ty til de gamle kunder på læsesalen, som tit passerede katalogværelset. Både Povl Engelstoft og Morten Borup havde ord for at være utilnærmelige, men deres svar var kontante, tog et halvt minut, og man var som oftest hjulpet, før de strøg videre. I dag får telefoniske spørgsmål altid et grundigt svar, idet man ringer tilbage. Den praksis var ikke udviklet endnu - man gav den, der selv mødte frem, fortrinsstilling. Telefoniske spørgsmål, der kunne besvares ved hjælp af Læsesalens håndbøger, var det dog naturligt at afvikle omgående, og da der stod 10.000 bind derinde, klarede de noget. At søge i magasinerne, derimod, faldt udenfor de fordringer katalogværelset stillede til sig selv. Det overkommelige var dengang bestemmende, hvilket naturligvis ikke er det ideale.

Men på stille dage var der tid til at være imødekommende. Sommerformiddage, når solen lyste fra tidlig morgen, kunne forløbe næsten uden personlige henvendelser, højst et par telefoner. Så var der rigelig tid til det løbende arbejde, der var uafhængigt af ydre forhold. Der kunne rettes fejl, lægges alfabetiske sedler ned eller placeres i de systematiske kataloger. Dette punktarbejde egnede sig godt til stedet, fordi det ikke krævede den langvarige fordybelse, der får den fordybede til at sidde med et lukket an- 
sigt og se utilnærmelig ud, så ingen gæst tør forstyrre. En dag lød en aldrende, sprød kvindestemme i telefonen, fortalte at hun i dette øjeblik sad sammen med en gammel ven, de prøvede at memorere vers fra de unge dage. Og nu spurgte hun, om bibliotekaren ikke ville have den godhed at give dem den nøjagtige ordlyd af de vers, som $H$.C. Andersen havde skrevet til Riborg Voigt. Da Vogel-Jørgensens Bevingede ord stod indenfor rækkevidde, var det en let sag at læse ind i røret: To brune Øjne jeg nylig saae og Min Tankes Tanke ene Du er vorden. Den dag sad Carl Th. Dreyer som enlig gæst i katalogværelse og som ofte for enden af det ene bord. Da de uskyldige strofer lød, gik næsten et glad smil over hans ellers så strenge ansigt.

Blandt de mange udlændinge, som dukkede op, var ikke så få tyske gæster. De havde let ved at orientere sig, særlig i det ældre system, hvis alfabetiske sedler er nedlagt efter den gamle preussiske måde. For dem var der også meget at hente, da Det kongelige Bibliotek indenfor de germanske områder i sine samlinger ejer ikke få unikke eksemplarer, f.eks. Geschichte von D. Johann Fausten (1587) eller Antwerpen-udgaven (ca. 1519) af Ulen-spieghel. Denne har mange træsnit, og titelblad viser rytter med Uglspil bag på hesten . På alfabetisk seddel er noteret: Kun dette eksemplar kendes.

$$
\begin{aligned}
& 96-77 \\
& \text { Nicolans KRAGE: Christliche } \\
& \text { Ordming der Erlykew Stadt } \\
& \text { Myudew... Lübeck.1530 } \\
& \text { Tyse gost i hatal juarelse (pra Minden) } \\
& \text { gor opmarlesem p", at litte eles } \\
& \text { er mignes (efter at et etr.; Celle } \\
& \text { er gaeet talt) }
\end{aligned}
$$

Illustrationen viser, hvordan den tyske gæsts meddelelse om Nic. Krages tabte bog blev noteret og gik videre til pågældende afdeling. 
Med den anden verdenskrigs bogbrande kom der flere tab til. En besøgende fra Minden rejste sig således fra sin stol, gik med skuffen hen til den vagthavende og gjorde opmærksom på, at Nicolaus Krage: Christliche Ordnung der Erlyken Stadt Mynden (Lübeck 1530) nu også var blevet enestående, da det næstsidste eksemplar, det i Celle, var gået tabt. Så rigt på ældre tysk litteratur er Det kongelige Bibliotek, at Volkswagen-fabrikkerne idag betaler en gennemgang og formentlig en publikation omkring disse herligheder.

En elegant dameledsaget af en bredskuldret mand meldtesig og fik besvaret sit spørgsmål. Ledsageren bød en cigar til tak og betroede, at damen var Krupp von Bohlen-arving. Cigaren så stærk ud og gik videre til rektor Bruun, der som pensionist syslede med Samuel Butler d.æ. og var en af vore stamgæster. En uges tid efter kom han ind i katalogværelset og fortalte, at han aftenen før havde været sammen med nogle unge mennesker, der studerede tysk-franske relationer. Han havde tændt cigaren, fortalt dens historie og nydt røgen. Det havde de unge ikke, tværtimod set strengt på ham. Han havde taget mod bestikkese fra en af vor tids kanonkonger. Den morgen lo kynikerne i katalogværelset, inden rektor gik i gang med at finde de gamle tryk af Samuel Butler.

Den ældre engelske bogbestand er god, men kan ingenlunde nå $\mathbf{i}$ nærheden af den tyske. En svensker kom over fra Lund og rekvirerede ikke Samuel Johnson's Dictionary, men subskriptionsindbydelsen fra 1747, som må have stået på vore hylder i lange tider, mens førstetrykket af selve ordbogen først indgik i de år, da Eric Jacobsen købte ind for fode og erhvervede forsømte klassikere. Da vagthavende på en af de stille dage sad og lagde sedler ned ialfabetiskskuffe, stødte han på: M. Edgeworth:Forgive and forget. Transl. into Irish. Belfast 1833. På sedlen var med gammeldags håndskrift tilføjet: „N.B.Skal væreden første verdslige Bog trykt med Iriske Characteres, da alle forhen vare trykte med latinske Typer, endskj. Almuen ei kan læse dem." - Desværre kom der dengang ingen irer for at se, hvad biblioteket rummede af bøger på gælisk.

Fra andre lande kom i de år besøgende, enkelte fra Polen og CzekoSlovakiet: grå skikkelser som stod i døren og under et eller andet plausibelt påskud havde fået udrejsetilladelse for at se et eller andet på det fremmede bibliotek. Det var nu ikke hovedsagen. Lavmælt spurgte de, om det var muligt at få kontakt med danske fagfæller. Telefonen gik så til det institut, hvor der kunne være en imødekommende kollega. Det tøvende svar blev viderebragt så positivt som det var forsvarligt. Hvor lå det institut, hvor man godt ville tage en faglig drøftelse med den spørgende? Der blev peget på 
bykort og forklaret buslinier. Aldrig har Turistforeningens små Københavner-kort gjort så god nytte som i de dage.

Så var det festligere at tage mod gæster fra Amerika. De dykkede ned i slægtens danske forhistorie, sommetider med held. Men det var altid svært med sen-navne. Da de ofte skulle videre til Rebild, var det naturligt at henvise dem til Udvandrerarkivet i Aalborg, hvor chancerne var større.

Den mest kærkomne gæst fra U.S.A. var professor P.M. Mitchell, der varetog undervisning i dansk (og vistnok tysk) ved Urbana University, Illinois, har skrevet en dansk litteraturhistorie, en bog om Vilhelm Grønbech, udsendt bibliografiske værker og været medudgiver af tyske klassikere. Når undervisningen i Urbana ebbede ud, tog han med sin familie flyveren over havet. I vore kartoteker, særlig på Danske Afdeling, ses hans og hans elevers navne på værdifulde publikationer. Hvad han fandt i vore

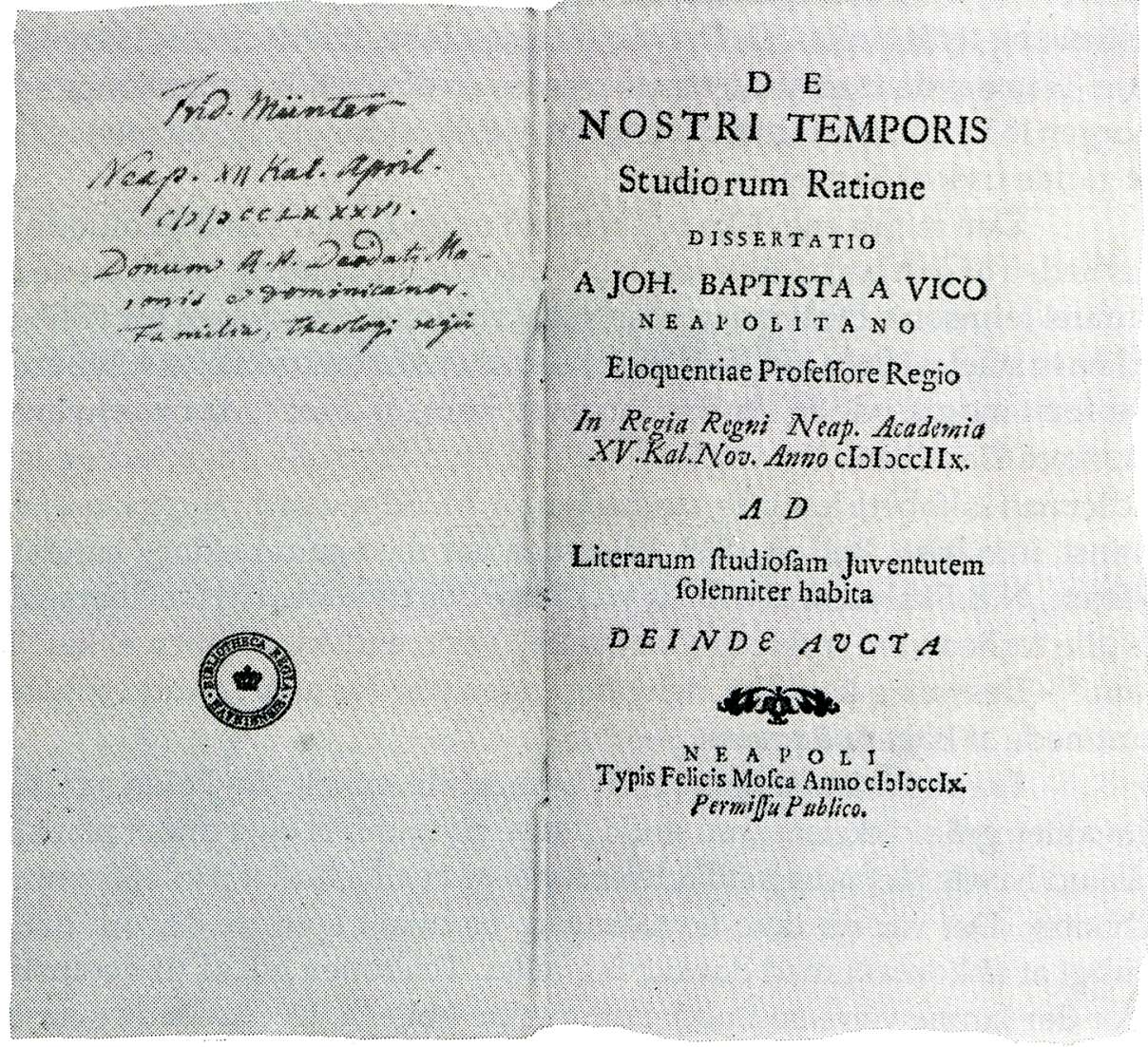

Vicos inauguraltale fra 1709 "Om vor tids måde at studere på" blev skænket Fr. Münter af en italiensk ven, da han besøgte Syditalien i 1786. 
kataloger og derpå fik ind på læsesal, gav han rigt tilbage i mange somres arbejde. Hvis vagten i katalogværelset ikke skulle have opdaget, at sommeren var kommet til Danmark, gik det op for ham den dag, Mitchell stod der, snurrende af arbejdsglæde.

Stimulerende var det ligeledes og en fornøjelse at se, hvordan besøgende italienere kunne reagere overfor bibliotekets italienske bogbestand. En mand fra Syditalien meddelte, at i et bestemt bibliotek i Napoli fandtes et eksemplar af Andrea de Jorio: La mimica degli antichi, investigata nel gestire napoletano. Med 21 tavler (Napoli 1832), sjældent og uopdriveligt. Den fortalte om italienernes mimiske kunst, alle de berømte gestus. Vi fandt den både i konsul Deonnas samling og i katalog 179III. Spørgeren trykkede i et øjebliks bevæget tavshed bibliotekarens hånd og talte derpå i strømme om sin store landsmand Giambattista Vico, grundlæggeren af moderne historiefilosofi, Herders forløber. Hvad havde vi af ham? Mellem gamle og nye tryk stod ungdomsværket: De nostri temporis studiorum ratione (Napoli 1709), ubeskåret i samtidigt karton med silkebånd. Nu bragede hans begejstring, jeg modtog hans omfavnelse. Hvordan var den bog endt i København? Fr. Münter, den senere biskop, havde som ung frimurer rejst omkring i Syditalien. Den vennesæle mand blev overalt modtaget af de italienske frimurere og hjemtog deres gaver.

$\mathrm{Nu}$ forstår jeg den oldnordiske poesi langt bedre og på en helt anden måde, var en italiensk parlamentarikers ord, da hun kom ind i katalogværelset for at sige farvel. Hun var kommet med bøn og hilsen fra De Gasperi om tilladelse til at seCodex Regius, håndskriftet med den ældre Edda. I de tider var det endnu ikke rejst nordpå, så det var gørligt. Hun sad og granskede den tætte skrift på det sortnede pergament, alt i een fortløbende tekst der ikke markerede versliniers begyndelser eller udgange. Det snævre skindstykke, man skrev på, tvang skriveren til at udnytte hver plet på siden og være sparsom på ord, fåmælt. Glad fortalte gæsten, hvordan det på eengang var gået op for hende, at materialet havde været med til at bestemme, at Nordens poesi blev så anderledes end Sydens. 